\title{
Vibration Monitoring of Rotating Systems
}

\author{
K. N. EDE ${ }^{1}$, E. A. OGBONNAYA ${ }^{2}$, M. T. LILLY ${ }^{3}$, S. O. T. OGAJI ${ }^{4}$, S. D. PROBERT ${ }^{4}$ \\ ${ }^{1}$ Method Engineer, Netco-Dietsmann Nigeria Limited, Port Harcourt, Nigeria \\ ${ }^{2}$ Department of Marine Engineering, Rivers State University of Science and Technology, Port Harcourt, Nigeria \\ ${ }^{3}$ Department of Mechanical Engineering, Rivers State University of Science and Technology, Port Harcourt, Nigeria \\ ${ }^{4}$ School of Engineering, Cranfield University, Bedfordshire, United Kingdom \\ E-mail: kingston2004@yahoo.com,ezenwaogbonnaya@yahoo.com,s.ogaji@cranfield.ac.uk \\ Received June 6, 2009; revised August 3, 2009; accepted August 10, 2009
}

\begin{abstract}
Most energy-conversion machines (e.g. vehicle engines and electric motors) involve rotating components (e.g. roller bearings and gears), which generate vibrations. The behavior of a pump which includes a deliberate fault was chosen to illustrate this assertion. The test bearing at the driven end of the pump's motor was deliberately damaged using a $1.5 \mathrm{~mm}$ wire-cutting method and an adjustable coupling disk introduced to impose a shaft misalignment of $4^{0}$. The resulting undesirable behavior of the pump was observed. Experimental data were measured at various speeds of the rotor. The sample period at various operating frequencies were $0.9,0.6$ and $0.45 \mathrm{~s}$ respectively. The ball-passage frequency was observed at $4.4,8.8,13.2$ and $17.6 \mathrm{~Hz}$. A computer-based analytical model was developed, in visual basic, for monitoring the machine failures: this led to an integrated system-process algorithm for diagnosis of faults in rotating components.
\end{abstract}

Keywords: Vibration Measurement, Rotating Component, Ball-Passage Frequency, Alarm Limit

\section{Introduction}

The use of vibration analysis as a fundamental tool for condition monitoring of equipment has evolved over the last 35 years. With parallel developments in electronic equipment, transducers and computers, the monitoring of machines is now almost completely automated. Onboard microprocessors provide the ability to capture pertinent measurements and analyze them via suitable algorithms, then store and display the conclusions. Several accelerometers, velocity transducers and displacement pick-ups have been developed and adapted to suit the pertinent requirement of industrial applications [1]. Modification of a rolling-element bearing activity monitor (REBAM) system offers a high signal-to-noise ratio relative to those for a casing-mounted accelerometer or velocity transducer, as shown in Figure 1 [2]. A system's signal-tonoise ratio is defined as the ratio of the amplitude of the desired signal to the amplitude of the noise signal. Increased signal-to-noise ratios for accelerometers have been achieved through the use of electronic filters [3].

REBAM vibration signals can be separated into rotorvibration and prime-spike regions. This signal separation improves the signal-to-noise ratio for both regions. By measuring directly the vibrations at the rolling-element bearing outer-ring and displacements are relative to the machine casing.

This isolates the signal of interest from extraneous vibrations (e.g., due to structural resonances, steam throttling, pump cavitation, gear noise, etc.) which often mask the bearing-defect signals when casingmounted transducers are employed. The results obtained indicate that this signal separation technique makes REBAM twice to eight times more sensitive to bearing faults than casing-mounted transducers [4]. A significant feature of this frequency analysis is the effective computation of the fast Fourier-transformation (FFT), which converts digital information from the time domain to the frequency domain and thereby achieves a more rapid spectral-analysis [5].

Long-term data storage is now a well accepted practice. However difficulties occurred when random-vibration

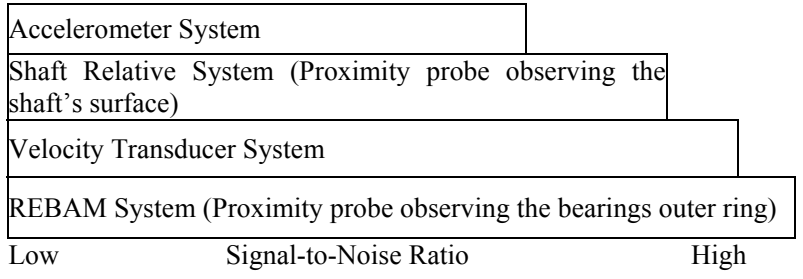

Figure 1. Qualitative indication of relative magnitudes of signal-to-noise ratios for various transducers. 
envelope spectrum algorithms for identifying defects in rolling-element bearings were applied to gearing. Extra lines appeared in the envelope spectrum due to the dynamic loads applied to the bearings by the gears. Additionally, spectral lines associated with the rolling-element detector based on the power spectrum [7]. The ensuant effective predictive maintenance can result in an $8 \%$ maintenance-cost saving and a further $8 \%$ increase in productivity [8], and hence the associated energy-thrift.

\subsection{Glossary}

An accelerometer, in the present context, is a transducer whose electrical or mechanical output is directly proportional to the acceleration experienced.

An alarm limit is the maximum permitted predicted value of the considered parameter, i.e. it indicates when attained that a dangerous situation is developing and so the alarm is triggered.

The ball-passage frequency is the frequency of the ball in a bearing component that will generate specific frequency dependent upon the bearing's geometry and its rotational speed.

The bearing-passage frequencies are the frequencies of rotation of the ball, outer race, inner race and cage.

A coupling-disc or flexible connecting system is a robust general purpose pin/buffer coupling, that facilitates a reliable fail-safe transmission of the torque between two nominally-coaxial shafts; it possesses the capability of being able to function despite a misalignment of the shafts.

A fast Fourier-transform is a numerical operation commonly used for transposing data rapidly from the time domain to the frequency domain, and usually accomplished via computer.

The gap, in the present context, is the air-filled separation between the rotor and stator.

Harmonics are components of a spectrum which are integral multiples of the fundamental frequency.

In the context of this article, imbalance (or a lack of balance) results from the distribution of mass according to the radial direction of the rotating system.

Outer-race-ball passage frequency is the rate at which a point on the specified rolling element passes a point on the outer bearing-race.

Inner-race-ball passage frequency is the rate at which a point on the specified rolling element passes a point on the inner bearing-race.

Prime spike is a term used by Bently Nevada to describe a vibration frequency range which includes those bearing frequencies that are generated by the rolling elements experiencing either an inner or outer race flaw.

A probe, in the present context, is a sensor capable of detecting the vibration signal.

The raceway is the ball passage frequency relative to the inner and outer ring of the bearing.

Rack-configuration software is a tool for configuring bearings occasionally disappeared from the spectrum. Investigations were conducted in order to overcome these complications [6]. This led to the introduction of the demerit of a bi-spectrum-based quickest-change detector, which was an extension of the analogous quickest integrated control-switching. It is designed to have a $3500 / 40$ proximity monitor and a four-channel monitor that accepts inputs that can trigger alarms.

Rolling-element frequency is the frequency at which either the balls or rollers revolve about their own centerlines in a bearing.

Ringing of the bearing occurs when ever the ball hits the flaw on the outer race of the bearing.

A signal, in the present context, is an electric voltage or current, which is an analogue of the vibration being measured.

In the context of this article, Spike energy is a measure of the energy generated by the repetitive impacts of the rolling elements against the defect in the bearing.

A time base is a horizontal line (representing time) about which the waveform representing the vibration signal occurs, i.e. the representation of a vibration signal in the time domain is a wave form.

A transducer is a device that converts the magnitude of one physical parameter into the value of another parameter, usually an electrical signal. The transducer used in vibration measurements is usually an accelerometer.

\section{The Aim}

This study investigates the occurrences of common machine-faults (i.e. rolling-element bearing and gear failures, misalignment of the shaft and imbalance of the shaft) that lead to energy wastages. The bearings were tested when undamaged and the resulting data were used as a bench-mark. An accelerometer was employed to obtain the vibration data from on-line measurements. The resulting information made available by the sensor and amplifier, was translated into useful knowledge about the forces on the machine and vibration patterns: the latter was classified according to the defects detected. Alarm limits were setup and programmed for the data collected. Faultdiagnosis software (FDS) for vibration monitoring of pumps and turbines has as a result been developed in this investigation: this is available from the authors.

\subsection{Instrumentation}

The characteristics of the employed standard vibrationmeasuring instrument for the applied range of 0.5 to $14000 \mathrm{~Hz}$, the power supply was a $4 \mathrm{~mA}$ constant current at $23 \mathrm{VDC}$, and 3 contact probes were available. Bently Nevada eddy-probes were installed on the test rig. A 3500/40 proximity four-channel monitor that accepts inputs to drive the alarms and programs is shown schematically in Figure 2. 


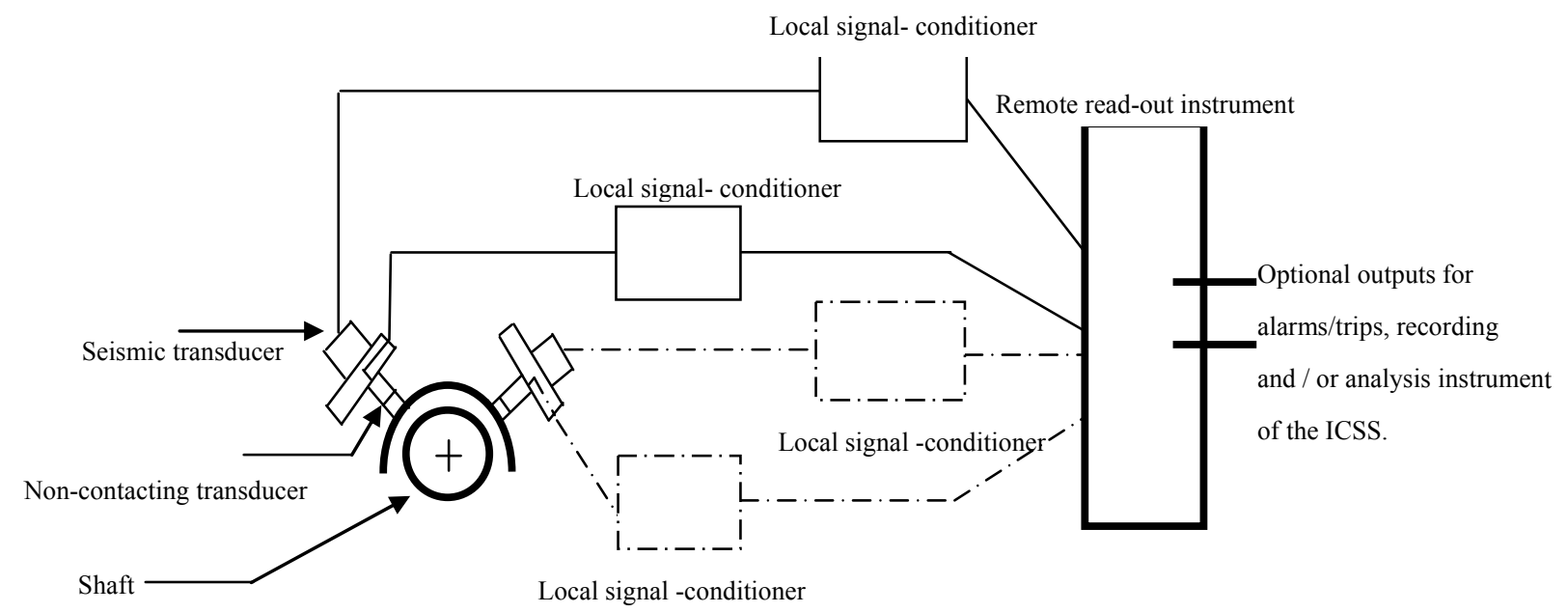

Figure 2. The probe arrangement.

\subsection{Time Period Sampled}

The relationship between frequency and time is given as:

$$
F=I / P
$$

For this analysis, the instrument was set up to observe the shaft rotating at 10 or 15 revolutions per second.

$$
\text { Total time }(s)=60 \text { (Number of Revolutions) } / R P M
$$

With this instrument used, it became necessary to set an equivalent $F_{\max }$ setting [9]. The appropriate $F_{\max }$ setting can be calculated as;

$F_{\text {max }}(C P S)$

= Lines of revolution $x$ RPM/60(No. of revolutions desired)

The SKF pattern No. 6226/C3 bearing used has a single row of balls. Because the defect was inflicted deliberately on the outer race of the ball bearing, at various speeds of the rotor, spikes were generated. These spikes corresponded to the outer race-ball passage frequencies [10]. Readings collected while using this damaged bearing is shown in table.

$$
O R B P=\frac{R P M}{2 * 60}\left(1-\frac{B_{d}}{P_{d}} \cos \theta\right) z
$$

The cage rotating frequency, $\left(i_{c}\right)[10]$.

$$
i_{c}=\frac{R P M}{2 * 60}\left(1-\frac{B_{d}}{P_{d}} \cos \theta\right)
$$

Table 1. Standard bearing 6226(SKF) used in this investigation.

\begin{tabular}{cccc}
\hline $\begin{array}{c}\text { Cage's Rotat- } \\
\text { ing-Frequency } \\
\left(i_{c}\right)\end{array}$ & $\begin{array}{c}\text { Inner } \\
\text { Race-Ball } \\
\text { Passage Fre- } \\
\text { quency } \\
(\text { IRBP })\end{array}$ & $\begin{array}{c}\text { Outer } \\
\text { Race-Ball } \\
\text { Passage Fre- } \\
\text { quency } \\
(\text { ORBP })\end{array}$ & $\begin{array}{c}\text { Rolling } \\
\text { Element } \\
\left(i_{R}\right)\end{array}$ \\
\hline 0.49 & 5.29 & 3.71 & 5.49 \\
\hline
\end{tabular}

A coupling disc was then designed so that it could impose a shaft misalignment onto the undamaged bearing. The disc was capable of moving relatively by adjusting the pin/buffer coupling. This forces the disc of $70 \mathrm{~mm}$ diameter on the shaft to move and produce an angular misalignment of $4^{0}$.

\subsection{Bench-Mark Alarm}

This type of alarm was used to trigger an alarm when the measured value exceeds its bench-mark value times a coefficient, which in this case WAS assumed to be 1.5. That is,

$$
\text { Threshold }=1.5 \text { (Bench mark value) }
$$

Vibration data were automatically compared with bench-mark values. User-defined alarm limits for the data collected are illustrated in Table 2.

\section{Results and Discussions}

The accelerometer was set up to record over a long timespan in order to observe the cycle of spike occurrences for probe data when the shaft was rotating at 10 or 15 revolutions per second. The periods necessary to accomplish 10 and 15 revolutions at 17 RPS were 0.6 and $0.9 \mathrm{~s}$ respectively, at 25 RPS are 0.4 and 0.6 s respectively, and

Table 2. User-defined upper and lower threshold alarmlimits.

\begin{tabular}{cc}
\hline Type of alarm & Definition of Alarm \\
\hline "High" & \\
DG+ + & DANGER if measured value $>$ DG+ \\
AL +0 & ALARM if AL $+<$ value $<$ DG + \\
AL- 0 & Otherwise acceptable. \\
DG- 0 & \\
"Low" & \\
DG+ 0 & DANGER if measured value $<$ DG- \\
AL+ 0 & ALARM if DG- $<$ value $<$ AL- \\
AL- 0 & Otherwise acceptable. \\
DG- 0 & \\
\hline
\end{tabular}


at 33 RPS are 0.3 and 0.45 seconds respectively.

When a ball was located near the point where the probe is mounted (left side, $45^{\circ}$ from the top) see Figure 3 , the outer race, due to the ball pressing on the defect, interacts and the resulting impacts excited a natural resonant frequency of the machine, caused the bearing to ring, and deform away from the bearing centre and towards the probe. This corresponds to the high peak-points in the time-domain plot shown in Figure 4.

\subsection{Damaged Bearing}

This was located at the driven-end bearing of the motor assembly and imposed by a flexible coupling to the AC motor. Three rotational speeds were used in the experiment to show the bearing-passage frequencies (see Table 3 ). The spectrum in Figure 5 indicates a mass imbalance of the shaft $(F 0)$ at $2 x$. The Outer Race-Ball Passage Frequency of the bearing at 17 RPS, i.e., the $2 x O R B P=8.2$.

Harmonic frequencies were generated due to $4^{0}$ misalignment of the shaft which disturbs the natural full motion of the shaft and this is often characterized by rubbing. The friction between the rubbing parts produced a broadband of high frequencies, some of the kinetic energy is released in the form of harmonic vibrations. The $2 x$ harmonics is indication of failure of the bearing, i.e. the most dominant amplitude. Lower frequency vibration was also transmitted through the coupling and even was amplified on the other end of the machine pump; this is indication of low amplitude on the frequency domain. However, the vibrations observed were often symptoms accentuating other vibration problems which gradually propagated and generated increased noise level and temperature of the equipment.

\section{Fault-Diagnostic Software (FDS) Program}

This program was written in visual basic. It is an online-based data simulation and monitoring process for a pump or turbine defects. The FDS was composed using rack-configuration software. For this reason, the flow chart shown in Figure 6 was developed to describe the adopted monitoring procedure. The process accepted basic process information, such as acquired data or signals from a PLC on the ICSS on-line [11]. The electronic control of the test equipment and the conventional connection of proximity probes for on-line data-acquisition via the PLC unit that was associated with the monitor (4-channel orbit analysis), therefore, was able to capture radial vibration, thrust position, and eccentricity. The module received input from many types of displacement transducers.

\subsection{Vibration Measurements}

To monitor this equipment on-line, the measured data were compared with their preset threshold values (in

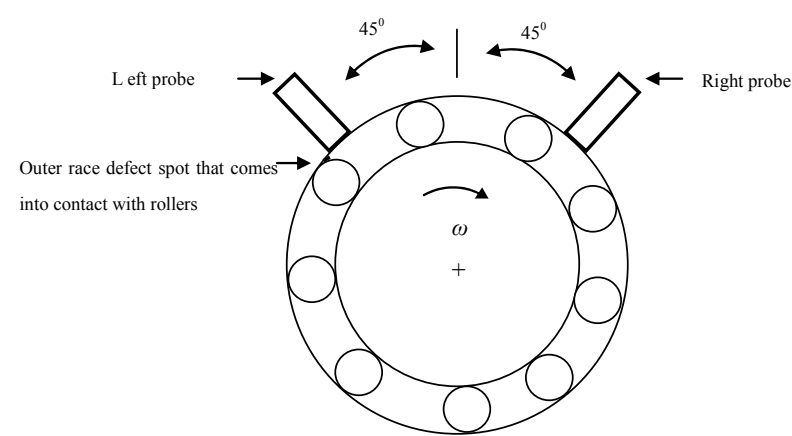

Figure 3. Probe orientations and outer race defect spot causing "ringing" of the bearing.

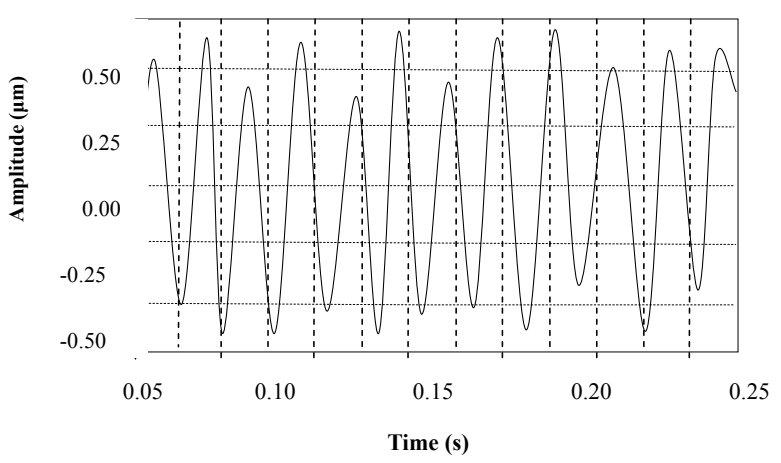

Figure 4. Outer-race deflection of the shaft which is rotating at 17 RPS.

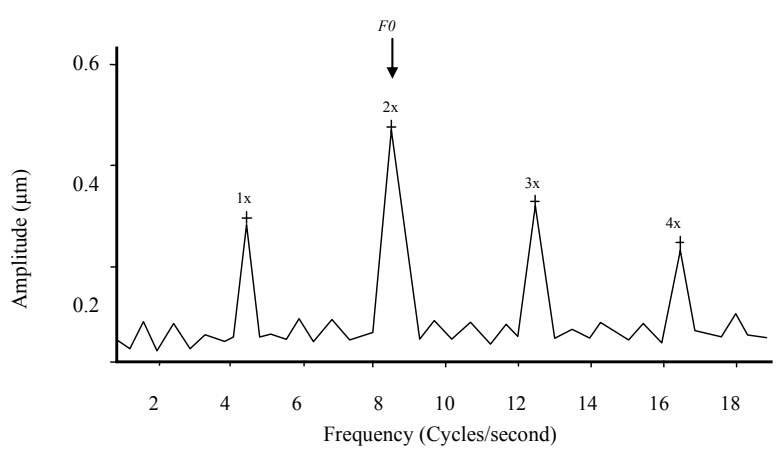

Figure 5. Frequency spectrum of the bearing operating at 17 RPS.

order to indicate alarm and danger).

\subsection{Simulation of All Alarms}

Three categories of alarm severity were observed during the series of tests.

1) Alert 1 (Yellow alarm) indicated that small in behavioral changes are occurring: it provides an early warning of a deteriorating situation, i.e. an on-line displacement defect, as seen in Tables 4(b) to 4(f) and Figure 7(a).

2) Alert 2 (Amber alarm) was the result of the next measurement and indicated that maintenance planning had to be scheduled. 
3) Danger (Red alarm). This serious situation requires immediate attention, as the measurements show consistent evolution of the defect(s), which was an indication of the severity observed as shown in Tables 4(a) to (e) for on-line imbalance and misalignment of the shaft, as shown in Tables 4(e) and 4(f) and Figures 7(c) and 7(d).

Table 3. Bearing-passage frequencies of the bearing.

\begin{tabular}{|c|c|c|c|}
\hline Shaft speed (RPS) & $\begin{array}{c}\text { Outer Race-Ball Passage Fre- } \\
\text { quency (cycles/second) }\end{array}$ & $\begin{array}{l}\text { Theoretically bearing-passage frequency } \\
\text { (cycles/second) } \\
\left(\text { ORBP }=z i_{c}\right)\end{array}$ & $\begin{array}{l}\text { Experimentally observed bear- } \\
\text { ing-passage frequency } \\
\text { (cycles/second) }\end{array}$ \\
\hline \multirow{4}{*}{17} & $1 \times O R B P$ & 4.4 & 4.1 \\
\hline & $2 \times O R B P$ & 8.8 & 8.2 \\
\hline & $3 \times O R B P$ & 13.2 & 12.3 \\
\hline & $4 \times O R B P$ & 17.6 & 16.4 \\
\hline \multirow{4}{*}{25} & $1 \times$ ORBP & 8.8 & 8.2 \\
\hline & $2 \times$ ORBP & 17.6 & 16.4 \\
\hline & $3 \times$ ORBP & 26.4 & 24.6 \\
\hline & $4 \times$ ORBP & 35.2 & 32.8 \\
\hline \multirow{4}{*}{33} & $1 \times$ ORBP & 13.2 & 12.3 \\
\hline & $2 \times$ ORBP & 26.4 & 24.6 \\
\hline & $3 \times$ ORBP & 39.6 & 36.9 \\
\hline & $4 \times$ ORBP & 52.8 & 49.2 \\
\hline
\end{tabular}

Table 4(a). On-line bench-mark measurements for undamaged bearing: December $14^{\text {th }}, 2005$.

\begin{tabular}{|c|c|c|c|c|c|}
\hline & $\begin{array}{c}2 \text { (DER) } \\
\text { Undamaged bearing }\end{array}$ & $\begin{array}{c}3 \text { (DER) } \\
\text { Damaged bearing }\end{array}$ & $\begin{array}{c}4 \text { (DER) } \\
\text { Undamaged bearing }\end{array}$ & $\begin{array}{c}5 \text { (NDEA) } \\
\text { Undamaged bearing }\end{array}$ & Alarm limit \\
\hline $\begin{array}{l}\text { Displacement of } \\
\text { shaft }(\mu \mathrm{m})\end{array}$ & 15.9 (Amber) & 26.5 (Amber) & 21.9 (Amber) & 22.9 (Amber) & $\begin{array}{c}\mathrm{DG}+60, \mathrm{AL}+40 \\
\mathrm{AL}-0, \mathrm{DG}-0\end{array}$ \\
\hline $\operatorname{Gap}(\mu \mathrm{m})$ & 1208 (Amber) & 1254 (Amber) & 1255 (Amber) & 1230 (Amber) & $\begin{array}{c}\mathrm{DG}+0, \mathrm{AL}+0 \\
\text { AL-1280, DG-1180 }\end{array}$ \\
\hline $\begin{array}{l}\text { Imbalance of } \\
\text { shaft }(\mu \mathrm{m})\end{array}$ & 10.09 (Amber) & 12.04 (Amber) & 11.12 (Amber) & 15.10 (Yellow) & $\begin{array}{c}\mathrm{DG}+20, \mathrm{AL}+15 \\
\mathrm{AL}-0, \mathrm{DG}-0\end{array}$ \\
\hline $\begin{array}{l}\text { Misalignment of } \\
\text { the shaft }(\mu \mathrm{m})\end{array}$ & 0.0076 (Amber) & 0.0011 (Amber) & 0.0070 (Amber) & 0.0056 (Amber) & $\begin{array}{c}\mathrm{DG}+.1, \mathrm{AL}+.05 \\
\mathrm{AL}-0, \mathrm{DG}-0\end{array}$ \\
\hline
\end{tabular}

Table 4(b). On-line results of undamaged and damaged bearing: April $2^{\text {nd }}, 2006$.

\begin{tabular}{|c|c|c|c|c|c|c|}
\hline & $\begin{array}{c}2 \text { (DER) } \\
\text { Damaged bear- } \\
\text { ing }\end{array}$ & $\begin{array}{c}3 \text { (DER) } \\
\text { Damaged bear- } \\
\text { ing }\end{array}$ & $\begin{array}{c}4 \text { (DER) } \\
\text { Undamaged } \\
\text { bearing }\end{array}$ & $\begin{array}{c}5 \text { (NDEA) } \\
\text { Undamaged } \\
\text { bearing }\end{array}$ & Alarm limit & Diagnosis \\
\hline $\begin{array}{l}\text { Displacement of } \\
\text { shaft }(\mu \mathrm{m})\end{array}$ & 50.9 (Yellow) & 42.5 (Yellow) & 41.9 (Yellow) & 58.2 (Yellow) & $\begin{array}{c}\mathrm{DG}+60, \mathrm{AL}+40 \\
\mathrm{AL}-0, \mathrm{DG}-0\end{array}$ & $\begin{array}{l}\text { Deterioration behavior } \\
\text { of displacement of the } \\
\text { shaft defects on the } \\
\text { motor bearing and } \\
\text { pump bearing. }\end{array}$ \\
\hline $\operatorname{Gap}(\mu \mathrm{m})$ & 1211 (Amber) & 1254 (Amber) & 1255 (Amber) & 1270 (Amber) & $\begin{array}{c}\mathrm{DG}+0, \mathrm{AL}+0 \\
\mathrm{AL}-1280 \\
\mathrm{DG}-1180\end{array}$ & There is no gap defect \\
\hline $\begin{array}{l}\text { Imbalance of } \\
\text { shaft }(\mu \mathrm{m})\end{array}$ & 16.13 (Yellow) & 14,04 (Amber) & 16.16 (Yellow) & 17.91 (Yellow) & $\begin{array}{c}\mathrm{DG}+20, \mathrm{AL}+15 \\
\mathrm{AL}-0, \mathrm{DG}-0\end{array}$ & $\begin{array}{l}\text { Imbalance of the shaft } \\
\text { defects on the motor } \\
\text { bearing and pump } \\
\text { bearing. }\end{array}$ \\
\hline $\begin{array}{l}\text { Misalignment of } \\
\text { the shaft }(\mu \mathrm{m})\end{array}$ & 0.0885 (Yellow) & 0.0918 (Yellow) & 0.0880 (Yellow) & 0.0911 (Yellow) & $\begin{array}{c}\mathrm{DG}+.1, \mathrm{AL}+.05 \\
\mathrm{AL}-0, \mathrm{DG}-0\end{array}$ & $\begin{array}{l}\text { Misalignment of the } \\
\text { shaft due to misalign- } \\
\text { ment of } 4^{0} \text { deliberately } \\
\text { introduced }\end{array}$ \\
\hline
\end{tabular}


Table 4(c). On-line results of undamaged and damaged bearing: April $3^{\text {rd }}, 2006$.

\begin{tabular}{|c|c|c|c|c|c|c|}
\hline & $\begin{array}{c}2 \text { (DER) } \\
\text { Damaged } \\
\text { bearing }\end{array}$ & $\begin{array}{c}3 \text { (DER) } \\
\text { Damaged } \\
\text { bearing }\end{array}$ & $\begin{array}{c}\text { (DER) } \\
\text { Undamaged bear- } \\
\text { ing }\end{array}$ & $\begin{array}{c}5 \text { (NDEA) } \\
\text { Undamaged } \\
\text { bearing }\end{array}$ & Alarm limit & Diagnosis \\
\hline $\begin{array}{l}\text { Displacement of } \\
\text { shaft }(\mu \mathrm{m})\end{array}$ & 51.9 (Yellow) & 45.5 (Yellow) & 44.9 (Yellow) & 60.9 (Red) & $\begin{array}{c}\mathrm{DG}+60, \mathrm{AL}+40 \\
\mathrm{AL}-0, \mathrm{DG}-0\end{array}$ & $\begin{array}{l}\text { Displacement of the } \\
\text { shaft defects on the } \\
\text { motor bearing and } \\
\text { pump bearing. }\end{array}$ \\
\hline $\operatorname{Gap}(\mu \mathrm{m})$ & 1235 (Amber) & 1255 (Amber) & 1259 (Amber) & 1271 (Amber) & $\begin{array}{c}\mathrm{DG}+0, \mathrm{AL}+0 \\
\mathrm{AL}-1280, \mathrm{DG}-1180\end{array}$ & There is no gap defect \\
\hline $\begin{array}{l}\text { Imbalance of } \\
\text { shaft }(\mu \mathrm{m})\end{array}$ & 21.84 (Red) & 18.01 (Red) & 28.19 (Red) & 25.11 (Red) & $\begin{array}{c}\mathrm{DG}+20, \mathrm{AL}+15 \\
\mathrm{AL}-0, \mathrm{DG}-0\end{array}$ & $\begin{array}{l}\text { Imbalance of the shaft } \\
\text { defects on the motor } \\
\text { bearing and pump } \\
\text { bearing. }\end{array}$ \\
\hline $\begin{array}{l}\text { Misalignment of } \\
\text { the shaft }(\mu \mathrm{m})\end{array}$ & $\begin{array}{l}0.0921 \text { (Yel- } \\
\text { low) }\end{array}$ & $\begin{array}{l}0.0941 \text { (Yel- } \\
\text { low) }\end{array}$ & 0.0841 (Yellow) & 0.0971 (Yellow) & $\begin{array}{c}\mathrm{DG}+.1, \mathrm{AL}+.05 \\
\mathrm{AL}-0, \mathrm{DG}-0\end{array}$ & $\begin{array}{l}\text { Misalignment of the } \\
\text { shaft due to misalign- } \\
\text { ment of } 4^{0} \text { deliberately } \\
\text { introduced }\end{array}$ \\
\hline
\end{tabular}

Table 4(d). On-line results of undamaged and damaged bearing: April $4^{\text {th }}, 2006$.

\begin{tabular}{|c|c|c|c|c|c|c|}
\hline & $\begin{array}{c}2 \text { (DER) } \\
\text { Damaged } \\
\text { bearing }\end{array}$ & $\begin{array}{c}3 \text { (DER) } \\
\text { Damaged } \\
\text { bearing }\end{array}$ & $\begin{array}{c}4 \text { (DER) } \\
\text { Undamaged } \\
\text { bearing }\end{array}$ & $\begin{array}{c}5 \text { (NDEA) } \\
\text { Undamaged } \\
\text { bearing }\end{array}$ & Alarm limit & Diagnosis \\
\hline $\begin{array}{l}\text { Displacement of } \\
\text { shaft }(\mu \mathrm{m})\end{array}$ & 51.9 (Yellow) & 45.7 (Yellow) & 50.1 (Yellow) & 61.9 (Red) & $\begin{array}{c}\mathrm{DG}+60, \mathrm{AL}+40 \\
\mathrm{AL}-0, \mathrm{DG}-0\end{array}$ & $\begin{array}{l}\text { Displacement of the } \\
\text { shaft defects on the } \\
\text { motor bearing and } \\
\text { pump bearing. }\end{array}$ \\
\hline Gap $(\mu \mathrm{m})$ & 1273 (Amber) & 1254 (Amber) & 1265 (Amber) & 1273 (Amber) & $\begin{array}{c}\mathrm{DG}+0, \mathrm{AL}+0 \\
\mathrm{AL}-1280 \\
\mathrm{DG}-1180\end{array}$ & There is no gap defect \\
\hline $\begin{array}{l}\text { Imbalance of shaft } \\
\qquad(\mu \mathrm{m})\end{array}$ & 28.09 (Red) & 25.19 (Red) & 34.19 (Red) & 34.17 (Red) & $\begin{array}{c}\mathrm{DG}+20, \mathrm{AL}+15 \\
\mathrm{AL}-0, \mathrm{DG}-0\end{array}$ & $\begin{array}{c}\text { Evolution of Imbalance } \\
\text { of the shaft defects on } \\
\text { the motor bearing and } \\
\text { pump bearing. }\end{array}$ \\
\hline $\begin{array}{l}\text { Misalignment of } \\
\text { the shaft }(\mu \mathrm{m})\end{array}$ & 0.1032 (Red) & 0.1117 (Red) & 0.1011 (Red) & 0.1322 (Red) & $\begin{array}{c}\mathrm{DG}+.1, \mathrm{AL}+.05 \\
\mathrm{AL}-0, \mathrm{DG}-0\end{array}$ & $\begin{array}{l}\text { Misalignment of the } \\
\text { shaft due to misalign- } \\
\text { ment of } 4^{0} \text { deliberately } \\
\text { introduced }\end{array}$ \\
\hline
\end{tabular}

Table 4(e). On-line results of undamaged and damaged bearing: April $5^{\text {th }}, 2006$.

\begin{tabular}{|c|c|c|c|c|c|c|}
\hline & $\begin{array}{c}2 \text { (DER) } \\
\text { Damaged bear- } \\
\text { ing }\end{array}$ & $\begin{array}{c}3 \text { (DER) } \\
\text { Damaged bear- } \\
\text { ing }\end{array}$ & $\begin{array}{c}4 \text { (DER) } \\
\text { Undamaged } \\
\text { bearing }\end{array}$ & $\begin{array}{c}5(\mathrm{NDEA}) \\
\text { Undamaged } \\
\text { bearing }\end{array}$ & Alarm limit & Diagnosis \\
\hline $\begin{array}{l}\text { Displacement of } \\
\text { shaft }(\mu \mathrm{m})\end{array}$ & 52.5 (Yellow) & 54.5 (Yellow) & 54.0 (Yellow) & 66.5 (Red) & $\begin{array}{c}\mathrm{DG}+60, \mathrm{AL}+40 \\
\mathrm{AL}-0, \mathrm{DG}-0\end{array}$ & $\begin{array}{l}\text { Displacement of the } \\
\text { shaft defects on the } \\
\text { motor bearing and } \\
\text { pump bearing. }\end{array}$ \\
\hline Gap $(\mu \mathrm{m})$ & 1279 (Amber) & 1264 (Amber) & 1275 (Amber) & 1277 (Amber) & $\begin{array}{c}\mathrm{DG}+0, \mathrm{AL}+0 \\
\mathrm{AL}-1280 \\
\mathrm{DG}-1180\end{array}$ & There is no gap defect \\
\hline $\begin{array}{l}\text { Imbalance of shaft } \\
\qquad(\mu \mathrm{m})\end{array}$ & 28.94 (Red) & 29.81 (Red) & 35.34 (Red) & 34.31 (Red) & $\begin{array}{c}\mathrm{DG}+20, \mathrm{AL}+15 \\
\mathrm{AL}-0, \mathrm{DG}-0\end{array}$ & $\begin{array}{c}\text { Evolution of Imbalance } \\
\text { of the shaft defects on } \\
\text { the motor bearing and } \\
\text { pump bearing. }\end{array}$ \\
\hline $\begin{array}{l}\text { Misalignment of } \\
\text { the shaft }(\mu \mathrm{m})\end{array}$ & 0.1051 (Red) & 0.1314 (Red) & 0.1108 (Red) & 0.1535 (Red) & $\begin{array}{c}\mathrm{DG}+.1, \mathrm{AL}+.05 \\
\mathrm{AL}-0, \mathrm{DG}-0\end{array}$ & $\begin{array}{l}\text { Misalignment of the } \\
\text { shaft due to misalign- } \\
\text { ment of } 4^{0} \text { deliberately } \\
\text { introduced }\end{array}$ \\
\hline
\end{tabular}


Table 4(f). On-line results of undamaged and damaged bearing: April $6^{\text {th }}, 2006$.

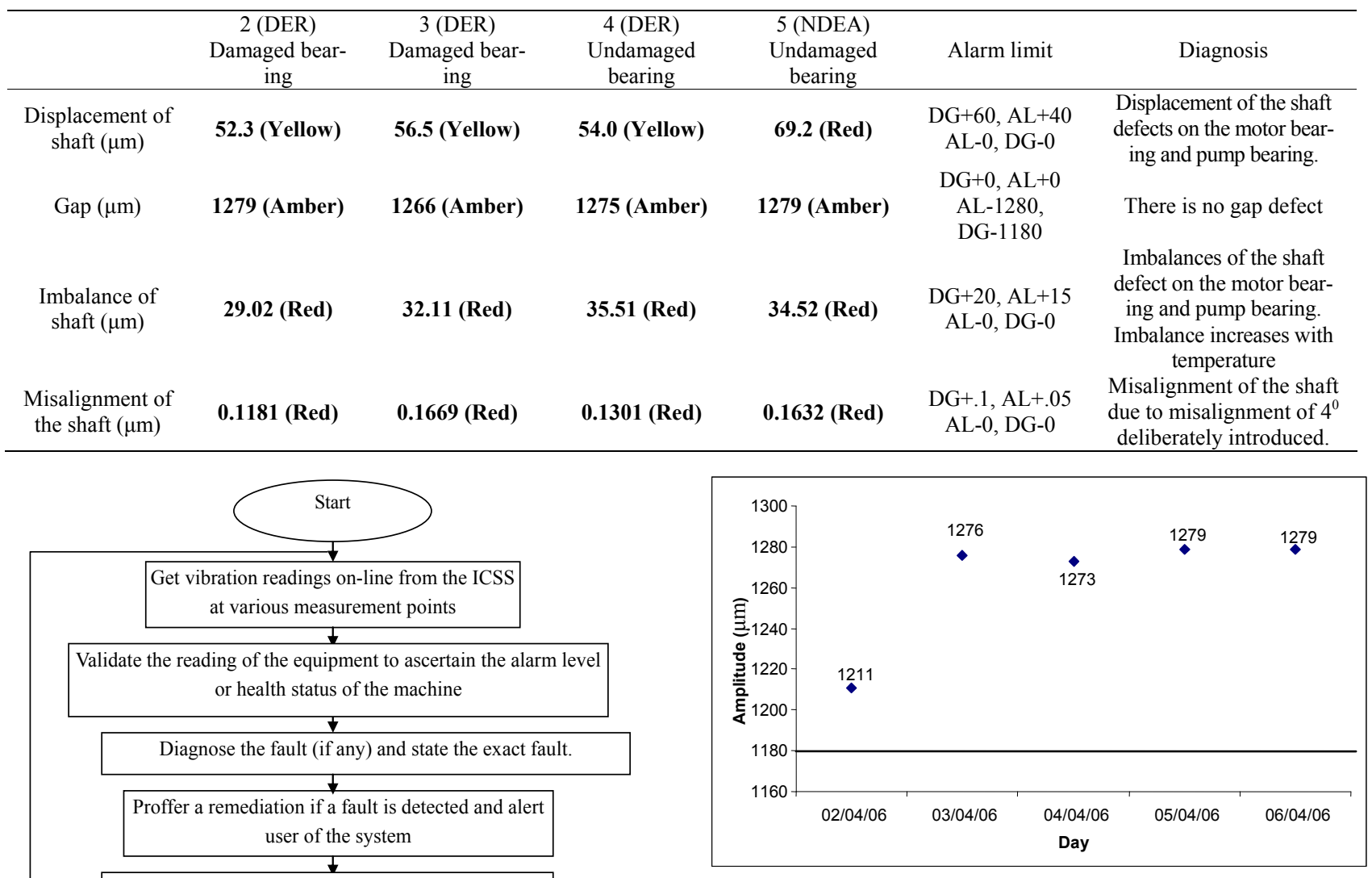

Figure 7(b). On-line gap defect for the 2 (DER) motor bearing.

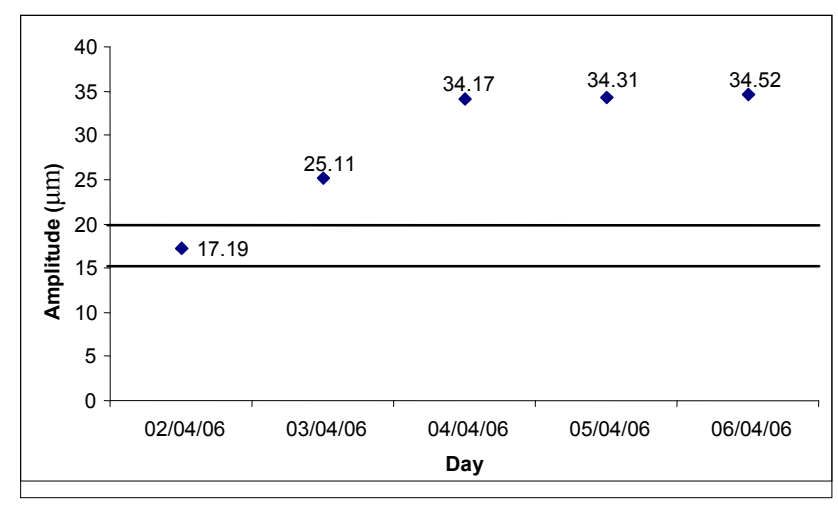

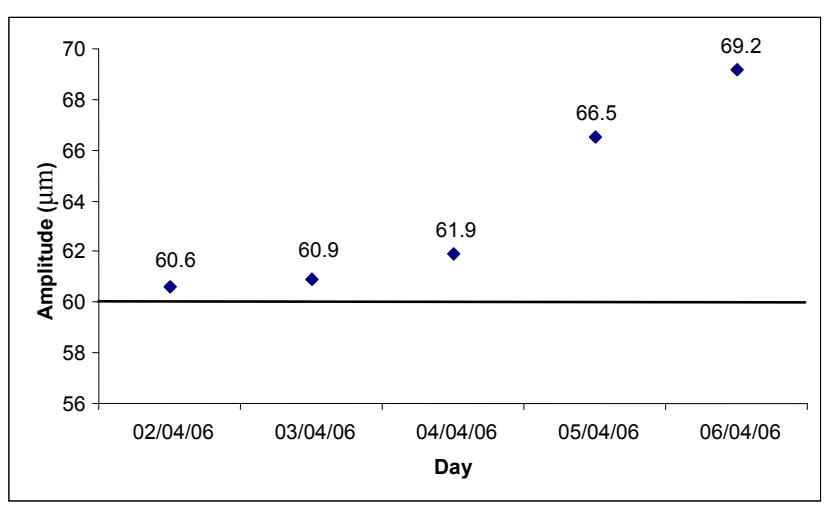

Figure 7(a). On-line displacement of shaft defect for the 5 (NDEA) pump bearing.
Figure 7(c). On-line imbalance of shaft defect for the 5 (NDEA) undamaged pump bearing.

\section{Conclusions}

These series of tests were set up to observe shaft rotations for speeds of $10 \rightarrow 15$ revolutions per second, and all key events were noted. Installed probes, on the driven end of the damaged bearing of the motor that was used for measuring the outer race deflections, also were used to monitor the misalignment and imbalance of the shaft. Defect locations in the raceway were determined from the spike locations in the frequency domain. 


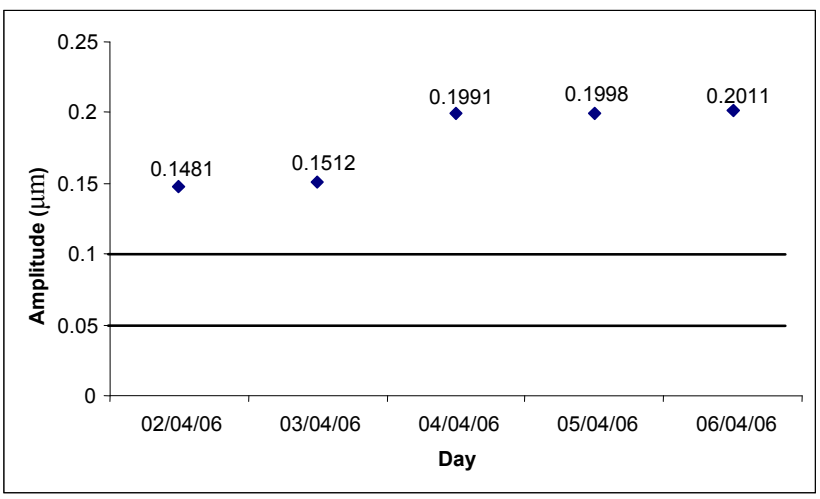

Figure 7(d). On-line misalignment of the shaft defect for the 3 (DEA) motor bearing.

Time-waveform analysis is an excellent analytical tool for fault diagnosis and prognostics: it enhances FFT information for on-line monitoring.

\section{Recommendations}

Accurately diagnosing and locating faults in machinery involving rotating components (e.g. pumps and turbines) can be achieved effectively by on-line vibration monitoring. This practice will reduce the waste of energy, effort expenditure, time consumption and drudgery experienced with off-line data-acquisition procedures and will facilitate wiser, maintenance decision making.

\section{Acknowledgements}

The authors wish to thank Netco-Dietsmann Nigeria Limited and Aminam/Kpono Field-Nigeria for logistics support and the provision of vital information that led to the successful execution of this work.

\section{References}

[1] R. Wilfried, S. Ulrich, P. Oliver, S. Christian, and W. B. Fiedrich, "Basics of vibration monitoring for fault detec- tion and process control," Non-Destructive Testing Department, Institute of Materials Science, University of Hanover, Garbsen, Germany, pp. 23-28, 2003.

[2] J. S. Hansen, Harker, and G. Roger, "A new method for rolling-element bearing monitoring in the petrochemical industry," Proceeding of the Vibration Institute Machinery Vibration Monitoring and Analysis Meeting, New Orleans, pp. 34-45, 1984.

[3] D. E. Bently, "Monitoring rolling-element bearings," Orbit Article, Bently Corporation, Nevada, pp. 12-23, 1982.

[4] D. B. Spencer and J. S. Hensen, "Better way to monitor bearings," Hydrocarbon Processing, pp. 2-7, 1985.

[5] E. A. Ogbonnaya, "Thermodynamics of steam and gas turbines," Oru's Press Ltd, Port Harcourt, Nigeria, pp. 11, 2004.

[6] V. B. Alexej and N. A. Bakorva, "Diagnostics of gearing and geared couplings using envelope spectrum methods," Vibro Acoustical Systems and Technologies (VAST), Inc., Saint-Petersburg, Russia, 1994. Online Available: http://www.vibrotek.com/bio/anb.htm.

[7] B. E. Parker Jr, H. V. Poor, E. C. Larson, T. A. Hamilton, and J. P. Frankel, Noise Conference, Proceedings of the Statistical Change Detection Using Non-Linear Models, USA, pp. 319-324, 1997.

[8] S. David, "Predictive intelligent machining and machinemonitoring sensors," March Consulting Group (Managing Maintenance into the 1990's), 1989. Online Available: http://www.vibanalysis.co.uk/the author/about. html.

[9] 01db Steel Technologies, Metravib, 2001. Online Available: http://www.01db-metravib.com (Assessed 26 December, 2005).

[10] A. V. Barkov and N. A. Barkova, "Automatic diagnostics of rolling-element bearings using enveloping methods," Proceedings of the 18th Annual Meeting, The Vibration Institute, USA, pp. 21-23, 1995.

[11] E. A. Ogbonnaya and K. E. Koumako, "Basic automatic control," King Tovic International, Port Harcourt, Nigeria, pp. 109-116, 2006. 


\section{Abbreviations, Nomenclature and Units}

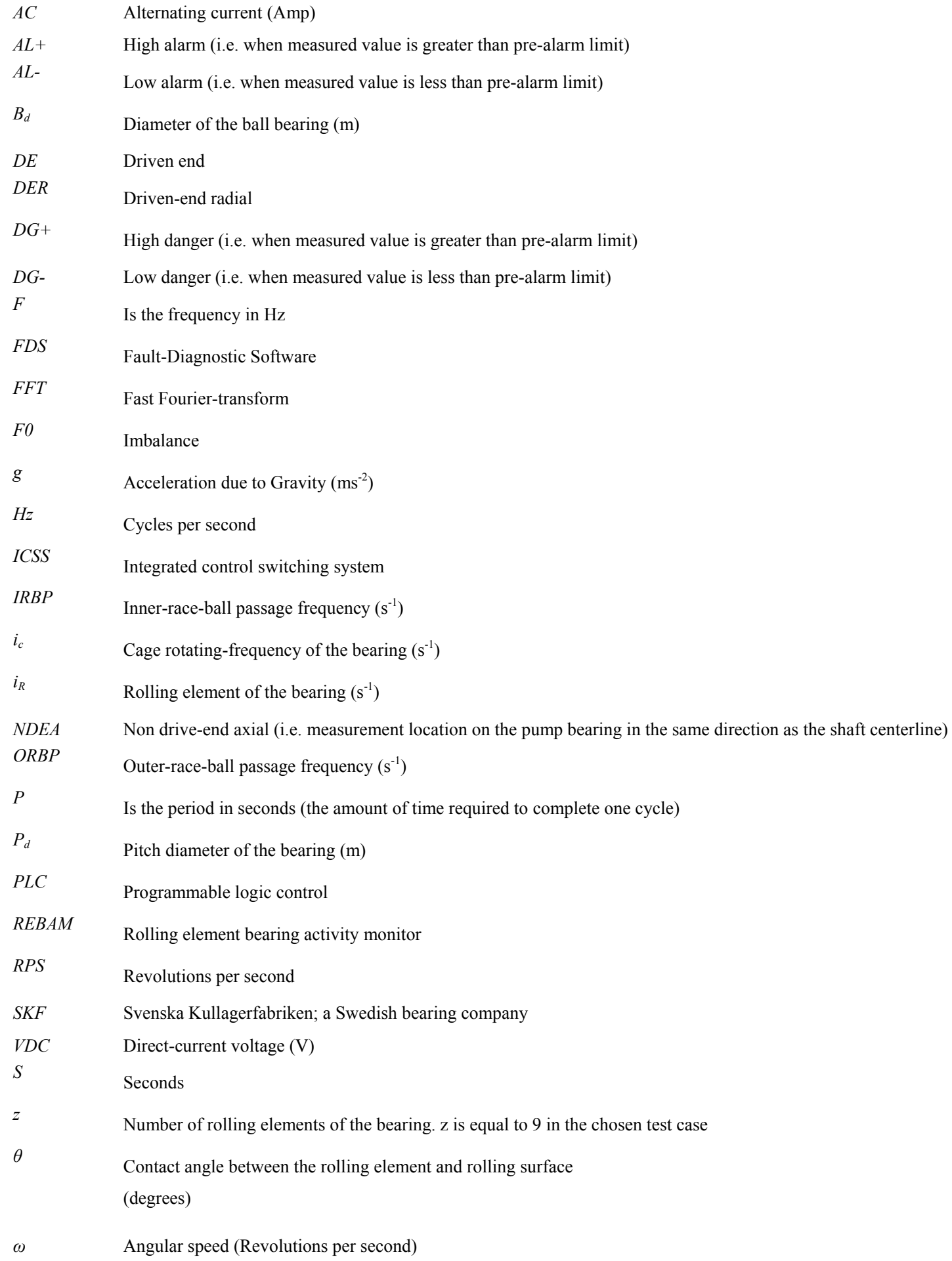

